\author{
О. І. ВОЛЬЧЕНКО ${ }^{1}$, В. С. СКРИПНИК ${ }^{1}$, Д. Ю. ЖУРАВЛЬОВ ${ }^{1}$, О. М. ВУДВУД \\ П. С. КPACIH
}

${ }^{1}$ Івано-Франківський національний технічний університет нафти і газу, Украйна

${ }^{2}$ Одеський національний політехнічний університет, Украӥна

${ }^{3}$ Кубанський державний технологічний університет, Росія

\title{
ТЕРМОСТАБІЛІЗАЦІЙНИЙ СТАН МЕТАЛЕВИХ ФРИКЦІЙНИХ ЕЛЕМЕНТІВ ГАЛЬМІВНИХ ПРИСТРОЇВ (ЧАСТИНА I)
}

У матеріалах статті розглянуто і обтрунтовано на основі теплового балансу та темпу нагрівання і вимушеного охолодження ободу гальмівного барабана автотранспортного засобу, умови виникнення його термостабілізаційного стану. Термостабілізачійний стан гальмівного барабана залежсть від теплової та електричної складових. При першому етапі у лабораторних умовах шияхом нагрівання визначають час теплового насичення ободу і флания гальмівного барабана автотранспортного засобу. При другому - визначаються втрати теплоти радіаиійним $i$ природним конвективним теплообміном від гальмівного барабана автотранспортного засобу, нагрітого вище допустимої температури для матеріалу фрикиійної накладки. При третьому етапі в експлуатаційних умовах визначаються втрати теплоти кондуктивним теплообміном від частин поверхонь фланців гальмівних барабанів автотранспортних засобів при їх взаємодії з поверхнями фланців маточин заднього моста автотранспортного засобу А. При четвертому етапі - в експлуатаційних умовах ијикічними гальмуваннями доводять тепловий стан пар тертя заднього гальмівного механізму вище допустимого для матеріалу фрикиійних накладок на $275-350{ }^{\circ} \mathrm{C}$ i фіксують ковзаючими термопарами їх поверхневі температури. При дотику двох електропровідних фаз, якими є поверхневі шари пар тертя гальмівних пристроїв, між ними виникає різниия електричних потенціалів, що пов'язано з утворенням подвійного електричного шару, тобто несиметричного розподілу заряджених частинок на границі розділу фаз. У разі роботи полімерної накладки в режимі вище допустимої температури для ї̈ матеріалів відбувається вигоряння їх сполучних (формальдегідної смоли) $i$ утворення острівиів рідини (електроліту) на робочій поверхні накладки. Таким чином, отримуємо перший електролітичний розчин. Другим електричним розчином є зрошувана вода, яка потрапляє на незахищені поверхні металевого фрикиійного елементу між його мікровиступами. В останніх знаходяться продукти зносу пар тертя, які змішуються з водою. Надалі відбувається зіткнення двох електролітичних розчинів з різними концентрачіями, щяо сприяє виникненню різничі електричних потенціалів. Останні виникають внаслідок наявності градієнтів температури і концентраиії та називаються термодифузійними потенціалами. Поліровані і матові поверхні гальмівних шківів мають різну топографію мікровиступів. Остання для матових поверхонь шківа є постійною, а для бігової доріжки шківа - змінною через його фрикційну взаємодію. При иьому поруч із субмікрорельєфом в прочесі експлуатації обода шківа на його біговій доріжиі тертя утворюється особлива зона мікрорельєфа, яка має висоту мікронерівностей на декілька порядків більше, ніж у субмікрорельєфа. Виникнення і формування подвійних електричних шарів в діапазоні температур нижче $і$ вище допустимої температур для матеріалів фрикційних накладок відіграє істотну роль в контактній взаємодії їх поверхонь з поверхнями металевого елемента тертя. Каталізатором для електронів та іонів є внутрімня поверхня ободу гальмівного барабана автотранспортного засобу. Слід 
зауважити, щзо каталізатор не ініціює взаємодію, з одного боку, іонізуючі повітряні потоки, щзо омивають робочі поверхні пар тертя гальм, а також газових сумішей, щуо виділилися з приповерхневих шарів накладок. 3 другого боку, тобто зовнішньої (матової) поверхні ободу гальмівного барабана автотранспортного засобу омивається зустрічними потоками повітря при русі транспортного засобу. Каталізатор тільки прискорює реакиї̈ на взаємодію, які можуть відбуватися $i$ у ї̈ відсутність, але значно повільніше. Виникнення термодифузї в потоках сумімей, щзо омивають робочу поверхню ободу гальмівного барабана автотранспортного засобу та фрикиійних накладок при розімкнутому барабанно-колодковому гальмі залежить від співвідношення об'ємів нагрітих і холодних їх марів. У барабанно-колодковому гальмі термодифузійний ефект в газовій суміші, шуо знаходиться 8 зазорах між їх парами тертя, спостерігається в тому випадку, якщо співвідношення об'ємів нагрітої і холодної частин газової сумімі змінюється за експоненційною залежністю. Міжфазова границя на блокуючій обичайці, якою є робоча поверхня гальмівного барабана автотранспортного засобу не пропускає носїв зарядів у двох напрямках.

Ключові слова: автотранспортний засіб, барабанно-колодкове гальмо, гальмівний барабан, фрикційна накладка, тепловий баланс, подвійні електричні шари, термостабілізаиіийний стан

Вступ. Металополімерні пари тертя важко навантажених фрикційних вузлів працюють при температурах, що перевищують допустиму для матеріалів фрикційних накладок, про що свідчать багаточисленні дослідження I. В. Крагельського, А. В. Чичинадзе, Б. І. Костецького та ін. вчених. Це призводить до дестабілізації експлуатаційних параметрів фрикційних вузлів i, як наслідок, до катастрофічного зниження їхньої ефективності і навіть аварійної відмови. Особливо небезпечним для них $є$ тривалий термостабілізаційний стан металевого елемента тертя, коли практично відсутня тепловіддача від його поверхонь. Уперше про цей стан згадано в працях О.Ф.Нефьодова й О.І.Вольченка. При цьому відбувається інтенсивне зношування робочих поверхонь фрикційних накладок і навіть їх руйнування, різке падіння динамічного коефіцієнта тертя та ефективності гальмування. Однією з основних умов виникнення термостабілізаційного стану металевого фрикційного елемента $є$ рівність темпів нагрівання та вимушеного його охолодження.

Стан проблеми. Зупинимося на енергонавантаженості гальмівних барабанів автотранспортних засобів.

Відомі методи визначення кількості теплоти (так званою калориметрією), які полягають у використанні різних типів калориметрів, а саме: звичайний калориметр змінної температури з ізотермічною оболонкою; масивний калориметр змінної температури з ізотермічною оболонкою; калориметри: змінної температури з адіабатичною оболонкою; сталої температури диференційний калориметр зі змінною температурою [1].

Проте представлені методи оцінки теплового балансу гальмівного барабана автотранспортного засобу не можуть бути використані з таких причин: через складність конфігурації поверхонь гальмівного барабана; не можливо врахувати вплив енергонавантаженості фланця барабана на його термостабілізаційний стан.

Відомо визначення критичної усталеної температури ободу гальмівного барабана автотранспортного засобу шляхом оцінки мінімальних температурних градієнтів по його товщині при температурах вище допустимої для матеріалів 
фрикційних накладок, які зумовлюють термостабілізаційний стан ободу барабана автотранспортного засобу на деякий проміжок часу [2]. Проте цьому методу притаманні такі недоліки: не беруться до уваги умови перерозподілу теплоти між ободом барабана та його фланцем; не враховуються термодеструкційні процеси в поверхневому шарі фрикційних накладок, що впливають на енергонавантаженість пар тертя гальма; не враховується процес інверсії теплових потоків від ободу барабана у приповерхневі шари фрикційних накладок.

А. В. Чичинадзе стверджує, що у металевому фрикційному елементі має місце температура насичення, але без обгрунтування іiі виникнення.

Постановка задачі. В даній публікації розглянуті наступні питання стосовно вирішувальної проблеми:

- оцінка енергонавантаженості ободу гальмівного барабана автотранспортного засобу в різних умовах:

- лабораторних;

- експлуатаційних;

- природа виникнення і формування подвійних електричних шарів на міжфазній границі пар тертя гальмівних пристроїв.

Мета роботи - оцінка інтенсивності перерозподілу теплових потоків між ободом барабана автотранспортного засобу та його фланцем з врахуванням темпів їх нагрівання і знаходження зони термостабілізації ободу барабана з урахуванням втрат на теплообмін при підтримці рівня термостабілізації інверсією теплових потоків від робочої поверхні ободу у приповерхневі шари фрикційних накладок, які піддаються термодеструкційним процесам.

\section{Оцінки енергонавантаженості ободу гальмівного барабана автотранс- портного засобу в різних умовах.}

\section{Лабораторних}

Термостабілізаційний стан гальмівного барабана залежить від теплової та електричної складових. Зупинимося спочатку на тепловому стані гальмівного барабана.

Перший етап. У лабораторних умовах шляхом нагрівання визначають час теплового насичення ободу і фланця гальмівного барабана автотранспортного засобу. Серійний гальмівний барабан 1 автотранспортного засобу має робочу поверхню 2 i фланець 3. По периметру робочої поверхні ободу 2 встановлені кільцеві електричні нагрівальні пристрої 4, які підключені до клем 5 електричного кола. При цьому кільцеві електричні нагрівальні пристрої 4 закриті з їх зовнішнього боку термоізоляційним кільцем 6. На зовнішній поверхні барабана 1 автотранспортного засобу встановлені термопари 8 з термоелектродами 9, підключеними до реєструвальної апаратури (на кресленні не показана) для фіксації термоЕРС, по тарованому графіку iї значення переводяться в температуру (рис. 1) [3, 4].

Перед нагріванням гальмівного барабана 1 автотранспортного засобу його встановлюють на підставку, виготовлену з матеріалу з низькою теплопровідністю, наприклад, ебоніту або текстоліту. Після чого під'єднюють нагрівальні пристрої 4 за допомогою клем 5 до електричної мережі. Нагрівальні пристрої 4 вмикають на час, протягом якого об'ємні температури ободу 2 і фланця 3 після усереднення виміряних їх температур, зафіксованих за допомогою термопар 8 , не стануть однаковими, тобто настане їх теплове вирівнювання. 


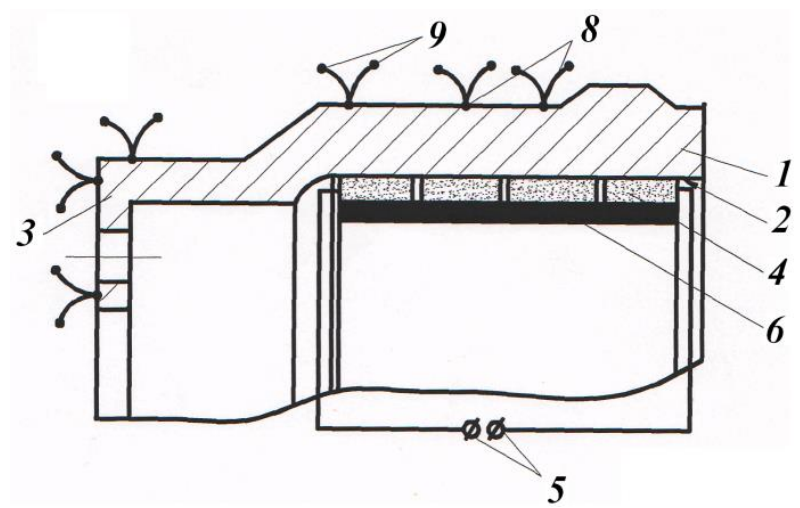

Рис.1 Конструкція нетеплоізольованого гальмівного барабана автотранспортного засобу

3 кільцевими електричними нагрівальними пристроями, розташованими на робочій поверхні його ободу

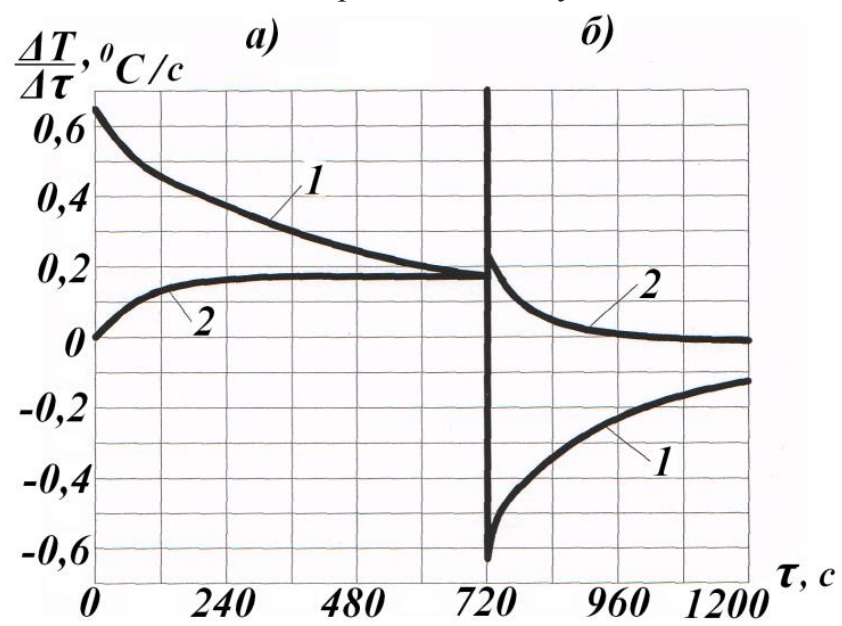

Рис. 2. Закономірності зміни темпів нагрівання $(a)$ і вимушеного охолодження (б) ободу (1) і бічної стінки (2) заднього гальмівного барабана автотранспортного засобу ЗІЛ-130 протягом випробовування типу II і після його завершення

a)

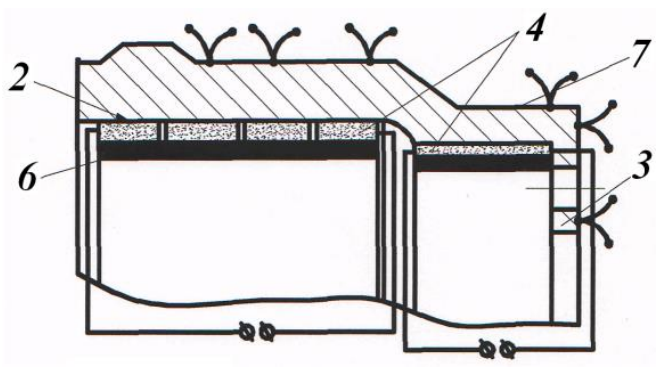

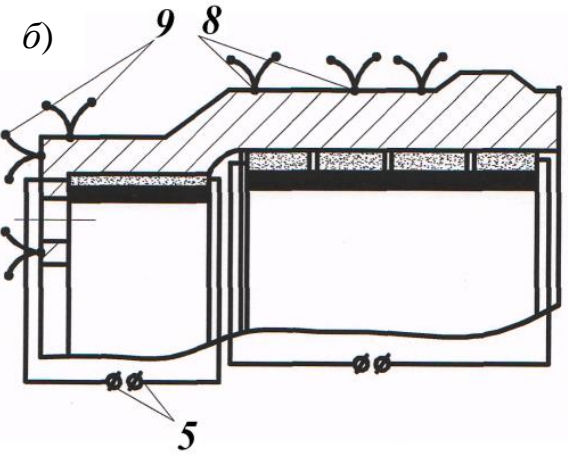

Рис. 3. Конструкції тепло ( $a$ ) - і не теплоізольованого (б) барабанів з кільцевими електричними нагрівальними пристроями, розташованими на робочих поверхнях їх ободів i на циліндричній перехідній ділянці до фланців барабана 
Характер зміни частки теплоти ободу барабана автотранспортного засобу та його бічної стінки в акумулюванні генерованої теплоти ілюструється (рис. 2) за допомогою темпів їх нагрівання протягом попереднього етапу випробувань гальма. Він проводиться гальмуванням, яке має здійснюватися або спуском загальмованого транспортного засобу із швидкістю 30 км/г по ділянці дороги довжиною 6,0 км з поздовжнім ухилом 6,0%, або певною кількістю циклічних гальмувань. Під час зазначених випробувань пари тертя барабанно-колодкових гальм автотранспортних засобів нагріваються.

Згідно 3 рис. 2 а темпи нагрівання ободу гальмівного барабана автотранспортного засобу та його бічної стінки визначали в інтервалі часу $0-720$ с за поліномінальною регресією вигляду:

$$
\begin{aligned}
& \frac{\Delta T}{\Delta \tau}=8,681 \cdot 10^{-7} x^{2}-1,217 \cdot 10^{-3} x+0,614 \\
& \frac{\Delta T}{\Delta \tau}=5,787 \cdot 10^{-7} x^{2}-5,952 \cdot 10^{-4} x+0,02
\end{aligned}
$$

Згідно з рис. 2 бемпи вимушеного охолодження ободу гальмівного барабана автотранспортного засобу та його бічної стінки визначали в інтервалі часу 0 480 с за поліномінальною регресією вигляду:

$$
\begin{aligned}
& \frac{\Delta T}{\Delta \tau}=-2,629 \cdot 10^{-6} x^{2}-2,137 \cdot 10^{-3} x+0,58 \\
& \frac{\Delta T}{\Delta \tau}=1,786 \cdot 10^{-6} x^{2}-1,324 \cdot 10^{-3} x+0,215
\end{aligned}
$$

Досягається термостабілізаційний стан ободу барабана автотранспортного засобу за рахунок того, що темп нагрівання ободу барабана автотранспортного засобу, який представляє собою швидкість зміни об'ємної температури ободу у часі, миттєво набуває від'ємного значення. Темп нагрівання його фланця при цьому різко зменшується. Це пояснюється тим, що фланець барабана автотранспортного засобу акумулює теплоту, його середня температура дорівнює температурі ободу барабана автотранспортного засобу. У кінцевому підсумку це призводить до термостабілізаційного стану ободу гальмівного барабана автотранспортного засобу. Такий стан, в більшості випадків, є можливим тоді, коли поверхнева температура в парі тертя досягає допустимої для матеріалів фрикційних накладок.

Другий етап. У лабораторних умовах визначаються втрати теплоти радіаційним і природним конвективним теплообміном від гальмівного барабана автотранспортного засобу, нагрітого вище допустимої температури для матеріалу фрикційної накладки на 275-350 ${ }^{\circ} \mathrm{C}$. Випробуванням піддають два серійних гальмівних барабана 1 автотранспортного засобу. У першому гальмівному барабані 1 автотранспортного засобу вся зовнішня поверхня покрита теплоізоляцією 7 (рис. $3, a$ ). По периметру робочої поверхні ободу 2 і циліндричної частини переходу до фланця 3 встановлено кільцеві електричні нагрівальні пристрої 4, які підключені до клем 5 незалежних електричних ланцюгів. При цьому кільцеві електричні нагрівальні пристрої 4 закриті з їх зовнішнього боку термоізоляційними кільцями 6. Другий гальмівний барабан 1 автотранспортного засобу має зовнішню поверхню нетеплоізольовану і взяту з першого етапу. Барабан 1 автотранспортного засобу дообладнується кільцевими електричними нагрівальними 
пристроями 4, підключеними до клем 5 електричного кола. Нагрівальний пристрій 4 закритий з його зовнішнього боку теплоізоляційним кільцем 6.

Перед нагріванням гальмівних барабанів 1 автотранспортних засобів їх встановлюють на підставки, виготовлені з матеріалу з низькою теплопровідністю, наприклад, ебоніту або текстоліту.

Після чого одночасно вмикають нагрівальні пристрої 4 в двох барабанах автотранспортних засобів за допомогою клем 5. Нагрівальні пристрої 4 вмикають на однаковий час, щоб температура робочої поверхні ободу 2 другого гальмівного барабана автотранспортного засобу 1 була понад $350{ }^{\circ} \mathrm{C}$ (рис. 3,6 ).

Потім від'єднюють нагрівальні пристрої 4 від електричної мережі і після усереднення заміряних об'ємних температур гальмівних барабанів автотранспортних засобів визначають величину їх відношення. Вона характеризує відношення об'ємної температури $\left(t_{2}-t_{0}\right)$ другого барабану до першого $\left(t_{1}\right)$, яке визначає частку теплоти, що розсіюється в навколишнє середовище радіаційним i природним теплообмінами. Так, наприклад, при співвідношенні зазначених температур частка теплоти, яка розсіюється в навколишнє середовище радіаційним і природним конвективним теплообміном від поверхонь барабана автотранспортного засобу, становить $15,2 \%$.

Оцінка теплового стану ободу гальмівного барабана автотранспортного засобу за прототипом і аналогом, показав такі переваги запропонованого температурного методу:

- можливість поетапного визначення теплових втрат конструктивними елементами гальмівного барабана автотранспортного засобу в лабораторних і експлуатаційних умовах;

- теплота, що вноситься в елементи гальмівного барабана автотранспортного засобу, доставляється електричними струмами за допомогою нагрівальних пристроїв в лабораторних умовах;

- визначення втрат теплоти, спричинене радіаційним і конвективним теплообміном, проводиться за однаковий час шляхом порівняння нагрітого нетеплоізольованого і теплоізольованого барабана автотранспортного засобу в лабораторних умовах;

- визначення втрат теплоти, зумовлене кондуктивним теплообміном проводиться за однаковий час шляхом порівняння нагрітого барабана автотранспортного засобу з барабаном, в якого теплоізольовано ділянку фланця в експлуатаційних умовах;

- оцінка часу вирівнювання температур між ободом барабана автотранспортного засобу та його фланцем за зміною темпів їх нагрівання. При цьому темп нагрівання ободу барабана автотранспортного засобу миттєво набуває від'ємного значення, а темп нагрівання його фланця різко зменшується.

Таким чином, при нагріванні обода гальмівного барабана автотранспортного засобу в лабораторних умовах з боку його робочої поверхні за допомогою кільцевих нагрівальних пристроїв відбувається наступне. У момент, коли термоелектроди термопар ободу і фланця барабана автотранспортного засобу покажуть майже однакову об’ємну температуру (настає їх теплове вирівнювання), темп нагрівання ободу барабана автотранспортного засобу миттєво набуває від'ємного значення, а темп нагрівання його фланця різко зменшується. 


\section{Експлуатаційних}

В експлуатаційних умовах оцінка теплового балансу гальмівного барабана має свою специфіку

Третій етап. В експлуатаційних умовах визначаються втрати теплоти кондуктивним теплообміном від частин поверхонь фланців гальмівних барабанів автотранспортних засобів при їх взаємодії з поверхнями фланців маточин заднього моста автотранспортного засобу.

Для реалізації третього етапу від гальмівних барабанів автотранспортних засобів від'єднують термоелетроди 9 термопар 8, а також електродроти нагрівальних пристроїв 4. 3 першого гальмівного барабана автотранспортного засобу знімають теплоізоляцію 7, залишивши ії тільки на ділянці теплоізольованого фланця 21 барабана автотранспортного засобу. Після чого гальмівні барабани автотранспортних засобів встановлюють в гальмівні механізми заднього моста, прикріплюючи їх до його фланця маточини 25 кріпильними болтами 23 ш шайбами 24 (рис. $4, a, \sigma$ ).

a)

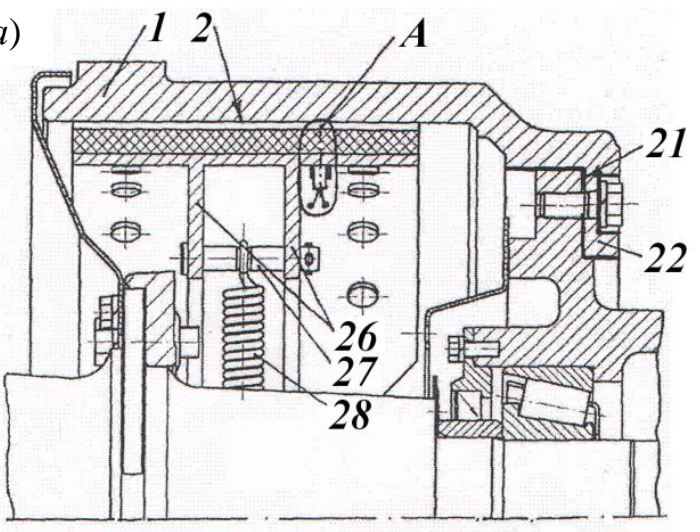

б)

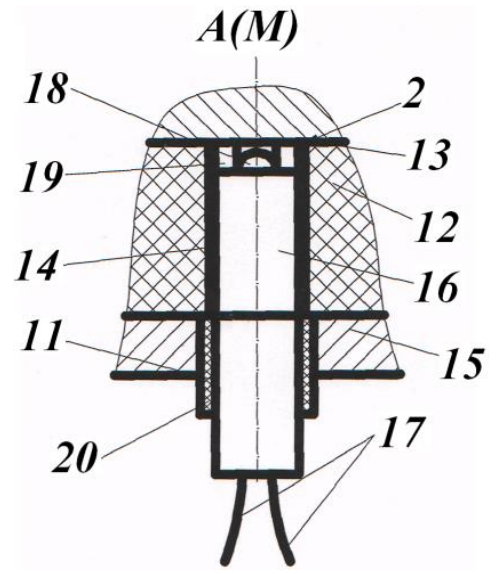

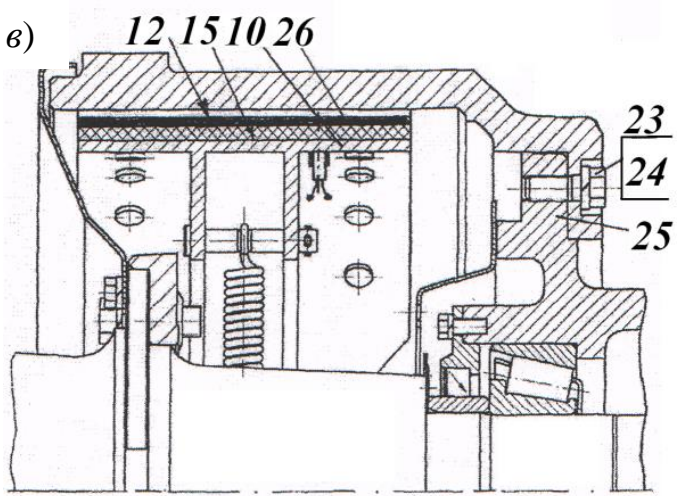

Рис. 4. Барабанно-колодкове гальмо (a) з вмонтованою термопарою у фрикційний вузлол (б) та $з$ ділянками теплоізольованого фланця барабана (в)

Для вимірювання поверхневих температур пар тертя барабанно-колодкового гальма заднього моста автотранспортного засобу в його накладках 12 розміщують термоелектроди 17 термопар 18 (див. рис. 4, в). Двоканальна керамічна трубка 16 встановлюється в отвір 14 накладки 12 і виводиться майже врівень іiі робочої поверхні 13. У трубі 16 діаметром 4,0 мм закладено термоелектроди 17 термопари 18, виготовленої з хромель-копелевого дроту діаметром 0,4 мм. До- 
датним термоелектродом 17 є хромелева дротина, а від’ємним - копелева дротина. Сферична головка термопари 18 , яка взаємодіє 3 робочою поверхнею 2 обода гальмівного барабана 1 автотранспортного засобу, сформована з високотемпературного мідного припою у вигляді спаю діаметром 3,0 мм і встановлена в обмежувальне кільце 19. Останнє перешкоджає виходу з ладу головки термопари 18 , сприяючи іiі роботі до повного зносу накладки. Двоканальна керамічна трубка 16 (керамічна трубка складається 3 двох частин) встановлена з ізоляційними втулками 20 і 21, в отвір 11 гальмівної колодки 15. Довжину термоелектродів 9 і 18 вибрано з умови, щоб за час експерименту холодний спай не встиг прогрітися, вона дорівнювала 200...350 мм. Вивід на реєструючу апаратуру здійснювали мідними дротами. Термопари 8 і 18 перед їх встановленням тарували разом із приєднювальними дротами.

Автотранспортний засіб розганяють до заданої швидкості і виконують його циклічні гальмування барабанно-колодковим гальмом шляхом прикладання i зняття зусилля з педалі гальма (на кресленні не показано), притискаючи за допомогою гальмівних колодок 15 накладки 12 робочими поверхнями 13 до робочої поверхні обода 2 барабана 1 автотранспортного засобу. Після завершення циклічних гальмувань автотранспортним засобом знімають навантаження з гальмівної педалі і за допомогою відтяжної циліндричної пружини 28 , кінці якої сидять на пальцях 27, відводять гальмівні колодки 15 з накладками 12 від робочої поверхні 2 барабана 1 автотранспортного засобу. При цьому в другому барабан автотранспортного засобу 1 теплота від його фланця 22 передається фланцю маточини 25 і тому температура робочої поверхні обода 2 першого барабана 1 автотранспортного засобу буде більше, ніж другого. Ця обставина сприяє різній інтенсивності радіаційного і вимушеного конвективного теплообміну від поверхонь барабанів 1 автотранспортних засобів. За величиною співвідношення виміряних поверхневих температур $\left(t_{1}-t_{0} / t_{2}-t_{0}\right)$ першого і другого барабанів автотранспортних засобів гальма судять про частку теплоти від загальної ії кількості, яка передається у фланець маточини 25 заднього моста автотранспортного засобу, тобто кондуктивним теплообміном. Так наприклад, при співвідношенні зазначених температур $\frac{350-20}{340-20}=1,093$ частка теплоти, яка передається кондуктивним теплообміном у фланець маточини 25 заднього моста автотранспортного засобу становить 9,3\%.

Четвертий етап. В експлуатаційних умовах циклічними гальмуваннями доводять тепловий стан пар тертя заднього гальмівного механізму вище допустимого для матеріалу фрикційних накладок на 275-350 ${ }^{\circ} \mathrm{C}$ і фіксують ковзаючими термопарами їх поверхневі температури. При поверхневих температурах пар тертя гальма 325-375 ${ }^{\circ} \mathrm{C}$ спостерігається вирівнювання об'ємних температур між фланцем 21 гальмівного барабана 1 автотранспортного засобу і його ободом. У поверхневому шарі 26 фрикційних накладок 12 гальма (рис. 4, a, в) спостерігаються термостабілізаційні процеси, спричинені фазовим переходом 1-го роду компонентів матеріалу накладки (випаровування і конденсація, плавлення і затвердіння, сублімація і конденсація в твердій фазі).

При фазовому переході 1-го роду стрибком змінюються такі параметри матеріалів фрикційної накладки, як густина, концентрація компонентів в одиниці об'єму матеріалу. При цьому виділяється і поглинається певна кількість теплоти, яка називається теплотою фазового переходу. Тому у трибологічній моделі приповерхневого шару фрикційної накладки необхідно розглядати три елементар- 
них об’єми з різними енергетичними рівнями: димлячий (стан сублімації), рідкий і пароподібний.

Найскладнішою, з точки зору процесів, що відбуваються, є рідка фаза.

Кожна фрикційна накладка колодки гальма має кривину робочої поверхні, i при високих температурах в елементарних об'ємах матеріалу з'являється рідина. Викривлення накладки зумовлює появу в ній додаткового капілярного тиску $\Delta p$, величина якого пов'язана $з$ середньою кривиною $r$ (рис. 5) поверхні рівнянням Лапласа:

$$
\Delta p=p_{1}-p_{2}=\frac{2 \sigma_{1,2}}{r},
$$

де $p_{1}, p_{2}-$ тиск в рідині 1 i контактуючого 3 нею середовищі (фазі); $\sigma_{1,2}-$ поверхневий натяг на границі двох середовищ.

Для опуклих поверхонь рідини ( $r>0) \Delta p>0$ капілярний тиск створюється силами поверхневого натягу, що діють по дотичній до поверхні розділу. Викривлення поверхні розділу зумовлює появу складової, спрямованої всередину об’єму однієї з контактуючих фаз.

Рух рідини в капілярах може бути спричинений різницею капілярного тиску, що виникає в результаті різної кривини поверхні рідини. Потік рідини спрямований в бік меншого тиску: для змочувальних рідин - до меніска з меншим радіусом кривини (рис. $5, a)$.

Зниження тиску пари над змочувальними менісками є причиною капілярної конденсації рідин в тонких шарах. Від'ємний капілярний тиск чинить стягуючу дію на обмежувальні рідину стінки (рис. 5, б). Зростання капілярного тиску при висушуванні призводить до значної усадки матеріалів.

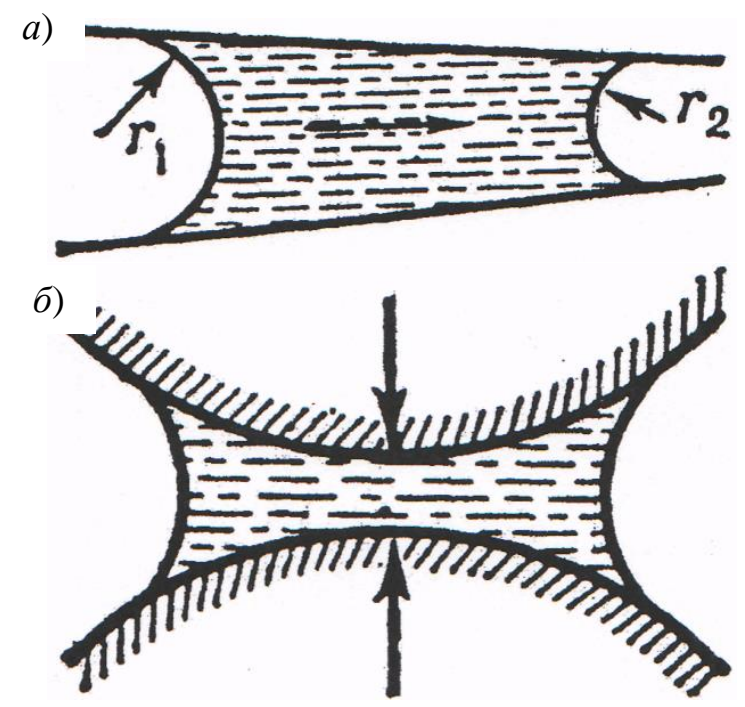

Рис. 5. Схеми капілярних ефектів в елементарному об'ємі фрикційного матеріалу накладки при: переміщенні рідини в капілярі під дією різниці капілярного тиску $\left(\mathrm{r}_{1}>\mathrm{r}_{2}\right)(a)$ та стягуючої дії капілярного тиску (б)

Природа виникнення і формування подвійних електричних шарів на міжфазній границі пар тертя гальмівних пристроїв.

При дотику двох електропровідних фаз, якими є поверхневі шари пар тертя гальмівних пристроїв, між ними виникає різниця електричних потенціалів, що по- 
в'язано з утворенням подвійного електричного шару, тобто несиметричного розподілу заряджених частинок на границі розділу фаз. На рис. $6, a, \sigma, e, ж$, , з, u, к, проілюстрований перехід заряджених частинок з однієї фази в іншу, що сприяє в розглянутих схемах утворенню подвійних електричних шарів. Однак стосовно пар тертя гальмівних пристроїв перерахований перелік не повний. Справа в тому, що до складу металевого (пояса тертя диска, обода шківа і барабана) і неметалевого (полімерні накладки) елементів входять напівпровідникові структурні складові. Крім того, через виникнення об'ємного заряду між мікровиступами, має місце масоперенос $з$ однієї фрикційної поверхні на іншу і навпаки. 3 вищевикладеного випливає, що утворюються нові пари тертя: «метал - полімер», «полімер - полімер», «метал - напівпровідник», «полімер - напівпровідник», «напівпровідник - напівпровідник», і отже, подвійні електричні шари, коли полімерна накладка працює в режимі нижче допустимої температури для ії матеріалів. При цьому згідно з рис. 6 відбувається виникнення наступних потенціалів: контактного другого роду $(a)$; контактного Вольта (в); електродного $(8,2)$; дифузійного $(\partial)$; адсорбційного $(e, \ldots, 3, i)$; іонно-адсорбційного $(\kappa)$.
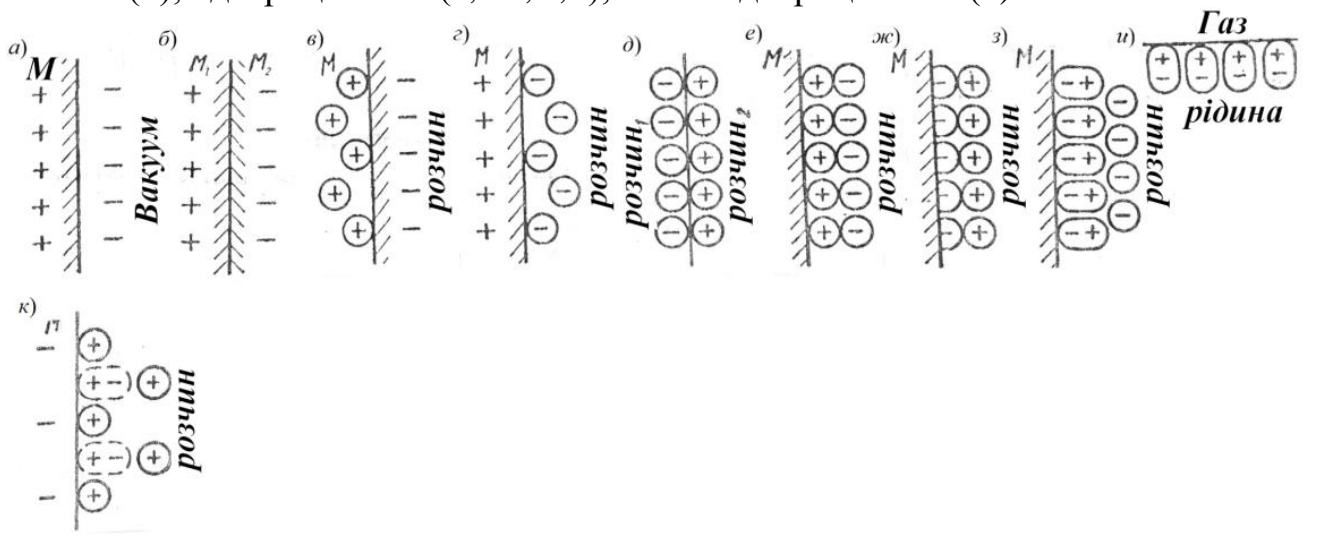

Рис. 6. Перехід заряджених частинок $з$ однієї фази в іншу: $a$-емісія електронів з металу в вакуум; $\sigma$ - перехід електронів з одного металу в інший; $\sigma$, г- перехід катіонів з металу в електроліт або з електроліту в метал; $\partial$ - нееквівалентний перехід іонів з одного електроліту в інший; виборча адсорбція заряджених або полярних частинок однієї фази на поверхні іншого електричного шару в межах однієї фази; $e$, - адсорбція катіонів або аніонів електроліту на поверхні металу; орієнтована адсорбція незаряджених полярних або поляризованих частинок на границі поділу, фаз в межах однієї фази; з - адсорбція молекул води на металі; $u$ - орієнтація дипольних молекул у поверхні розділу рідина газ; $\kappa$ - наявність іонно-адсорбційного шару при адсорбції поляризованих атомів кисню на поверхні металу в умовах переходу катіонів з металу в електроліт; у всіх розглянутих схемах відбувається утворення подвійного електричного шару

У разі роботи полімерної накладки в режимі вище допустимої температури для iї матеріалів відбувається вигоряння їх сполучних (формальдегідної смоли) і утворення острівців рідини (електроліту) на робочій поверхні накладки. Таким чином, отримуємо перший електролітичний розчин. Другим електричним розчином є зрошувана вода, яка потрапляє на незахищені поверхні металевого фрикційного елемента між його мікровиступами. В останніх знаходяться продукти зносу пар тертя, які змішуються з водою. Надалі відбувається зіткнення двох електролітичних розчинів 3 різними концентраціями, що сприяє виникненню різниці електричних потенціалів. 
Останні виникають внаслідок наявності градієнтів температури і концентрації і називаються термодифузійними потенціалами.

Поліровані і матові поверхні гальмівних шківів мають різну топографію мікровиступів. Остання для матових поверхонь шківа є постійною, а для бігової доріжки шківа - змінною через його фрикційну взаємодію. При цьому поруч із субмікрорельєфом у процесі експлуатації обода шківа на його біговій доріжці тертя утворюється особлива зона мікрорельєфа, яка має висоту мікронерівностей на декілька порядків більше, ніж у субмікрорельєфа.

Відомо, що на змочуваність поверхні пояса тертя впливає форма і рельєф канавок, частота і їх розташування та ефективна ширина. Цим збільшується безконтактна площа взаємодії, але зате зменшується коефіцієнт взаємного перекриття пар тертя гальма. Водяну канавку у фрикційному вузлі можна розглядати як закритий канал з кутом профілю $\varphi_{y}$ (рис. $\left.7, a\right)$.

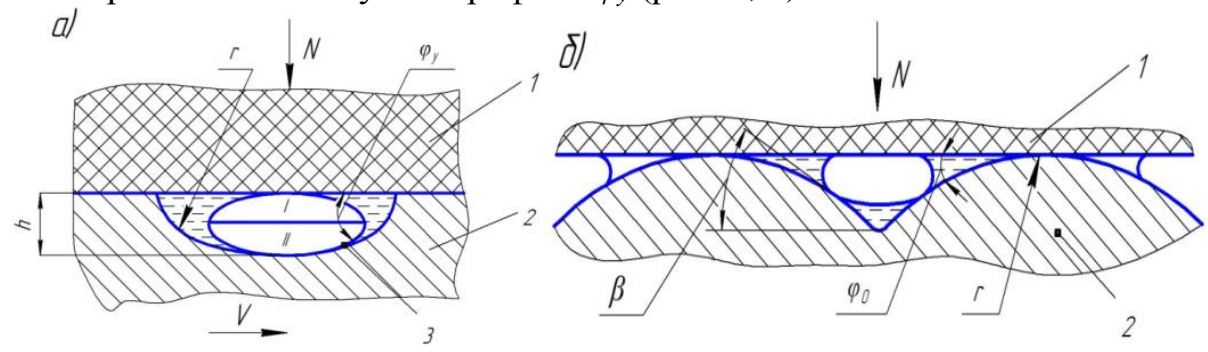

Рис. 7. Розтікання води між: парами тертя ( $a$ ) і їх мікровиступами (б) у стрічковоколодковому гальмі: 1 - фрикційна накладка; 2, 2'- обід шківа та його мікровиступи; 3 - адсорбований шар води

Із збільшенням радіуса канавки $r$ і зменшенні ії глибини $h$ кут $\varphi_{y}$ зменшується, і тому змочуваність та швидкість розтікання верхнього шару води впоперек канавки збільшується (рис. 7, б). При цьому формуються подвійні електричні шари (ПЕШ) - перший $(I)$ - «верхній напівшар води - робоча поверхня накладки»; другий $(I I)$ - «нижній напівшар води - поверхня канавки обода». Між напівшарами води виникає різниця потенціалів коли $\varphi_{\mathrm{I}}-\varphi_{\mathrm{II}}>0$ і нижній напівшар води нібито прилипає до поверхні канавки. Крім того, мікрогеометрія канавок на біговій доріжці тертя обода шківа впливає на теплоту десорбції нижнього напівшару води, що робить його більш непіддатливим.

Виникнення і формування (ПЕШ) у діапазоні температур нижче і вище допустимої температур для матеріалів фрикційних накладок відіграє істотну роль у контактній взаємодії їх поверхонь з поверхнями металевого елемента тертя.

Згідно з рис. 8, а поверхні пари тертя гальмівного пристрою зближені до молекулярних відстаней, тобто до відстаней порядку $10^{-10}$ м. При цьому робоча поверхня металевого елемента тертя віддає електрони робочій поверхні полімерної фрикційної накладки і вона накопичує їх. Так, у пограничному шарі виникає електричне поле з дуже короткими лініями. Його називають подвійним шаром, а напруження, що виникають в ньому, - контактним напруженням.

При виникненні подвійного шару по всій провідній поверхні взаємодії електричні заряди $+q$ i $-q$ зміщуються один відносно одного за рахунок сповільненого обертання металевого елемента тертя.

Встановлено, що мікроділянки поверхонь тертя, які мають залишкові напруження стиску, стають анодами, а не напружені - катодами (рис. 8, б). 

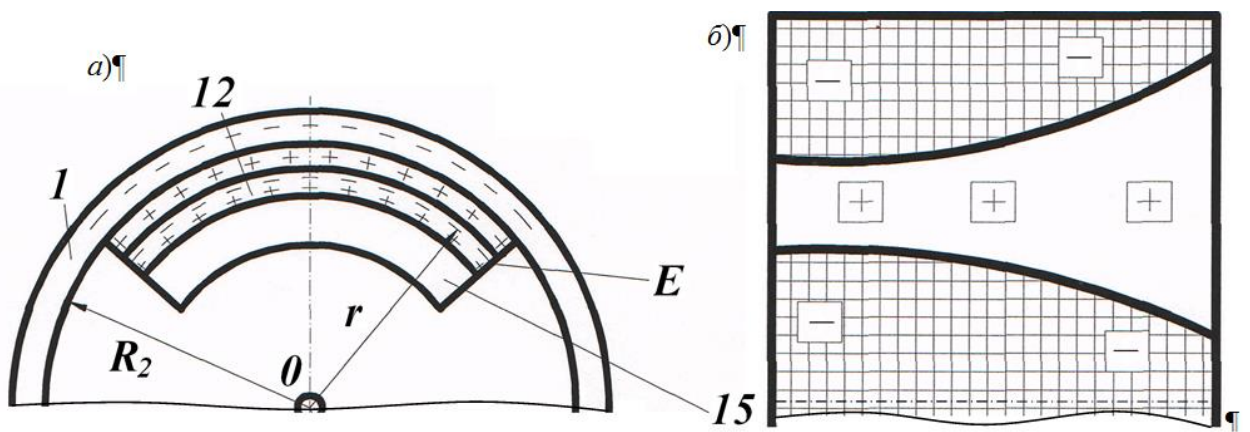

Рис. 8. Схема фрикційного вузла гальма у вигляді циліндричного конденсатора (a); вигляд зверху на фрикційну накладку (б)

Іонна адсорбція рідкої фази сполучних компонентів фрикційного матеріалу накладки характеризується тим, що наявні в ній тверді компоненти адсорбують різні іони тієї самої речовини по-різному. Так, іони, здатні поляризуватися, адсорбуються на поверхнях пар тертя гальмівних пристроїв, складених 3 полярних молекул або іонів.

Мікроділянки поверхонь пар тертя, які несуть певний заряд, адсорбують протилежно заряджені іони. При цьому іони рідкої фази сполучних компонентів фрикційних матеріалів, однойменно заряджені з робочою поверхнею накладки, безпосередньо на ній не адсорбуються, а під дією електромагнітних сил залишаються поблизу адсорбованих іонів, утворюючи разом з ними на поверхні адсорбенту (на робочій поверхні ободу гальмівного барабана) подвійний електричний шар. У цьому випадку адсорбційні процеси стають об'ємними.

Каталізатором для електронів та іонів $є$ внутрішня поверхня ободу гальмівного барабана автотранспортного засобу. Слід зауважити, що каталізатор не ініціює взаємодію, з одного боку, іонізуючі повітряні потоки, що омивають робочі поверхні пар тертя гальм, а також газових сумішей, що виділилися з приповерхневих шарів накладок. 3 іншого боку, тобто зовнішньої (матової) поверхні ободу гальмівного барабана автотранспортного засобу омивається зустрічними потоками повітря при русі транспортного засобу. Каталізатор тільки прискорює реакції на взаємодію, які можуть відбуватися і у ії відсутність, але значно повільніше.

Виникнення термодифузії в потоках сумішей, що омивають робочу поверхню ободу гальмівного барабана автотранспортного засобу та фрикційних накладок при розімкнутому барабанно-колодковому гальмі залежить від співвідношення об'ємів нагрітих і холодних їх шарів. У барабанно-колодковому гальмі термодифузійний ефект в газовій суміші, що знаходиться в зазорах між їх парами тертя, спостерігається в тому випадку, якщо співвідношення об'ємів нагрітої і холодної частин газової суміші змінюється за експоненційною залежністю. При температурах $300-350{ }^{\circ} \mathrm{C}$ на поверхнях пар тертя гальма (вище допустимої температури для полімерного матеріалу фрикційної накладки) досягає величини в 910 разів.

Будова (ПЕШ) поблизу твердої поверхні (металевого елемента тертя), яка має від'ємний заряд $\left(-\sigma_{\mathrm{m}}\right)$, наведено схематично на рис.9.

Поверхнева густина від'ємного заряду $\sigma_{\mathrm{M}}$ (потенціалоутворюючий шар) являє собою зовнішню циліндричну пластину конденсатора, а іони (катіони), які знаходяться в об’ємі приповерхневого шару накладки, утворюють внутрішню 
циліндричну пластину протилежного знаку [адсорбційна і дифузійна частина (ПЕШ)]. При цьому система в цілому є електронейтральною

$$
-\sigma_{\Delta}=\sigma_{1}+\sigma_{2}
$$

де $\sigma_{1}$ i $\sigma_{2}$ - щільність зарядів адсорбційного і дифузійного шарів.

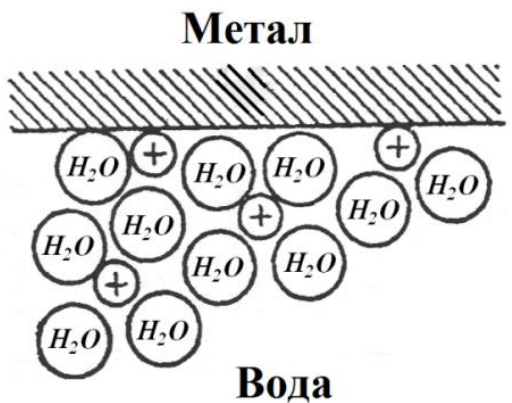

Рис. 9. Модель пограничного шару «метал - вода» при збільшенні потенціалу на даній границі

Використовуючи умову електронейтральності приходимо до висновку, що абсолютні значення зарядів по різні боки (ПЕШ), який являє собою циліндричний конденсатор з молекулярними обичайками, є рівними між собою. Застосувавши поняття поляризації об'ємного заряду, як захоплення заряджених носіїв на границі розділу фаз в результаті, їх вільного розряду, що відбувається, або зміни кількості носіїв на обичайках, що сприяє поляризації (деполяризації) об'ємного заряду (ПЕШ) при прикладанні до його обичайок зовнішньої різниці потенціалів (за рахунок тертя ковзання при взаємодії внутрішньої поверхні гальмівного барабана автотранспортного засобу з робочими поверхнями фрикційних накладок).

У цих умовах контактуючі фази трохи обмінюватимуться зарядами, а вся енергія зовнішнього електричного поля, що виробляється в результаті ковзання пар тертя гальма, витрачається на заряд (ПЕШ). Тоді в гальваностатичному режимі в границі потенціалів «ідеальної поляризованості» отримуємо лінійну залежність напруження від тривалості процесу поляризації. У цьому випадку ємність (ПЕШ) визначається за залежністю вигляду:

$$
c=\frac{2 \pi \varepsilon_{0} L}{\ln \frac{R_{2}}{R_{1}}}-\frac{S}{d},
$$

де $\varepsilon_{0}-$ діелектрична проникність шару Геймгольца, за яку приймають діелектричну проникність електроліту (його розчинника); $L$ - усереднена ширина взаємодії пар тертя гальмівних пристроїв; $R_{2}, R_{1}$ - радіус робочих поверхонь гальмівного барабана автотранспортного засобу та фрикційних накладок; $S$ i $d$ - активна площа робочої поверхні гальмівного барабана автотранспортного засобу і товщина (ПЕШ) [5].

Міжфазова границя на блокуючій обичайці, якою є робоча поверхня гальмівного барабана автотранспортного засобу не пропускає носіїв зарядів у двох напрямках. Фізична природа цього процесу полягає в тому, що формування (ПЕШ) зумовлено специфічною адсорбцією, поверхневими перетвореннями та ін., а не переходом заряду крізь саму границю [6]. Отже, (ПЕШ) на блокуючій обичайці являє собою своєрідний молекулярний конденсатор, заряди якого на останній 
спричинені перерозподілом електронів або заряджених точкових дефектів у поверхні гальмівного барабана автотранспортного засобу та іонів в електроліті приповерхневого шару фрикційних накладок.

Висновки. Таким чином, на основі теплового балансу та темпу нагрівання і вимушеного охолодження ободу гальмівного барабана автотранспортного засобу обгрунтовані умови виникнення його термостабілізаційного стану.

\section{Список літератури}

1. Кирилин В. А. Основы экспериментальной теромдинамики / В. А. Кирилин, А. Б. Шейдлин / М. - Л.: Государственное энергетическое издательство, 1950. - 310 с.

2. Вольченко А. И. Тепловой расчет тормозных устройств. Львов: Высшая школа. 1987. - $133 \mathrm{c}$.

3. Пат. 2525347 C2 Российская Федерация, МПК F16D 65/833, F16D 51/10. Способ нагревания и охлаждения тормозных барабанов барабанно-колодочного тормоза транспортного средства для оценки их теплового баланса / А. И. Вольченко, В. М. Павлиский, Н. А. Вольченко, Д. А. Вольченко, П. А. Поляков. заявитель и патентообладатель ИваноФранковск. национал. ун-т нефти и газа. №2012110869/11; заявл. 21.03.2012; опубл. 10.08.2014 Бюл. №22. - $11 \mathrm{c}$.

4.Пат. 2386061 C2 РФ, МПК F16D 49/08; F16D 65/813. Способ определения коэффициентов распределения тепловых потоков между парами трения различных типов фрикционных узлов в ленточно-колодочных тормозах буровых лебедок (варианты) / А. И. Вольченко, Д. А. Петрик, Н. А. Вольченко, Д. А. Вольченко; заявитель и патентообладатель Ивано-Франковск, национал. техн. ун-т нефти и газа. - №2007128496/11; заявл. 24.07.2007; опубл. 10.04.2010. Бюл. №10. - 14 с.

5.Проектный и проверочный расчет фрикционных узлов барабанно- и дисковоколодочных тормозов автотранспортных средств. Стандарт / А. Х. Джанахмедов, А. И. Вольченко, Н. А. Вольченко и др. Баку: Апострофф, 2016.264 с.

6. Ц Цветков Ф. Ф., Григорьев Б. А. Тепломассообмен. М.: Изд-во МЭИ, 2005. - 215 с.

Стаття надійшла до редакціїі 18.09.2020.

Вольченко Олександр Іванович - докт. техн. наук, професор кафедри технічної механіки Івано-Франківський національний технічний університет нафти і газе, вул. Карпатська, 15, м. Івано-Франківськ, Україна, 76000, тел..: +38 03427271 41, моб. 050950-04-18, E-mail: www.divo99@ukr.net.

Скрипник Василь Степанович - докт. техн. наук, професор кафедри автомобільного транспорту Івано-Франківський національний технічний університет нафти і газу, вул. Карпатська, 15, м. Івано-Франківськ, Україна, 76000, тел..: +38 03427271 41, моб. 050-950-04-18, E-mail: www.divo99@ukr.net.

Журавльов Дмитро Юрійович - канд. техн. наук, доцент кафедри технічної механіки Івано-Франківський національний технічний університет нафти і газу, вул. Карпатська, 15, м. Івано-Франківськ, Україна, 76000, тел..: +38 03427271 41, моб. 050-95004-18, E-mail: dmytro.2103@ukr.net.

Вудвуд Олександр Миколайович - канд. техн. наук, доцент кафедри підйонотранспортного та робототехнічного обладнання, Одеський національний політехнічний університет, Україна, 65044, м. Одесса, пр. Шевченка, 1.

Красін Павло Сергійович - канд. техн. наук, доцент кафедри матеріалознавства та автосервіса Кубанського національного технологічного університету, Росія. 


\section{O. I. VOLCHENKO, V. S. SKRIPNIK, D.YU. ZHURAVLEV, O. M. VUDVUD, P. S. KRASIN}

\section{THERMOSTABILIZATION STATE OF METAL FRICTION ELEMENTS OF BRAK- ING DEVICES (PART I)}

The materials of the article consider and substantiate, based on the heat balance and rate of heating and forced cooling of the rim of the brake drum of the vehicle, the conditions of its thermal stabilization state. The thermal stabilization state of the brake drum depends on the thermal and electrical component. At the first stage in laboratory conditions by heating determine the time of thermal saturation of the rim and the flange of the brake drum of the vehicle. In the second case, heat losses are determined by radiation and natural convective heat exchange from the brake drum of a motor vehicle heated above the allowable temperature for the friction lining material. In the third stage. under operating conditions, heat losses are determined by conductive heat exchange from parts of the surfaces of the flanges of the brake drums of vehicles in their interaction with the surfaces of the flanges of the hubs of the rear axle of the vehicle A when. the fourth stage in operating conditions by cyclic braking proves the thermal state of friction pairs of the rear brake mechanism above the allowable for the material friction pads at $275-350^{\circ} \mathrm{C}$ and fix the sliding thermocouples their surface temperatures. When two electrically conductive phases touch, which are the surface layers of friction pairs of brake devices, there is a difference of electric potentials, which is associated with the formation of a double electric layer, ie asymmetric distribution of charged particles at the phase interface. In the case of operation of the polymer overlay in the mode above the allowable temperature for its materials, their binders (formaldehyde resin) burn out and the formation of liquid islands (electrolyte) on the working surface of the overlay. Thus, we obtain the first electrolytic solution. The second electric solution is irrigated water, which falls on the unprotected surfaces of the metal friction element between its microprojections. In the latter are the products of wear of friction vapors, which are mixed with water. In the future, two electrolytic solutions collide with different concentrations, which contributes to the difference of electric potentials. The latter occur due to the presence of gradients of temperature and concentration and are called thermodiffusion potentials. Polished and matte surfaces of brake pulleys have different topography of microprojections. The latter is constant for the matte surfaces of the pulley, and variable for the treadmill of the pulley due to its frictional interaction. In this case, a special zone of microrelief is formed next to the submicrorelief during the operation of the pulley rim on its friction treadmill, which has a height of microroughnesses several orders of magnitude greater than that of submicrorelief. Occurrence and formation of double electric layers in the temperature range below and above the allowable temperature for friction lining materials plays a significant role in the contact interaction of their surfaces with the surfaces of the metal-friction element. The catalyst for electrons and ions is the inner surface of the rim of the brake drum of the vehicle. It should be noted that the catalyst does not initiate the interaction, on the one hand, ionizing air flows, washing the working surfaces of the friction pairs of the brakes, as well as gas mixtures released from the near-surface layers of the linings. On the other hand, ie the outer (matte) surface of the rim of the brake drum of the vehicle is washed by countercurrents of air when the vehicle is moving. The catalyst only accelerates the reactions to the interaction, which can occur in its absence, but much slower. The occurrence of thermal diffusion in the streams of mixtures that wash the working upper rim of the brake drum of the vehicle and friction pads with the drum drum pad open depends on the ratio of the volumes of heated and cold layers. In the bar-bath-brake brake, the thermodiffusion effect in the gas mixture, which is in the gaps between their friction pairs, is observed if the ratio of the volumes of the heated and cold parts of the gas mixture changes exponentially. The interfacial boundary on the blocking shell, which is the working surface of the brake drum of the vehicle, does not allow charge carriers in two directions. 
Keywords: motor vehicle, drum-pad brake, brake drum, friction pad, heat balance, double electric layers, thermal stabilization state

\section{References}

1. Kirilin V. A. Osnovy eksperimental'noy teromdinamiki / V. A. Kirilin, A. B. Sheydlin / M. - L.: Gosudarstvennoye energeticheskoye izdatel'stvo, 1950. - $310 \mathrm{~s}$.

2. Vol'chenko A. I. Teplovoy raschet tormoznikh ustroystv. L'vov: Vysshaya shkola. $1987.133 \mathrm{~s}$.

3. Pat. 2525347 S2 Rossiyskaya Federatsiya, MPK F16D 65/833, F16D 51/10. Sposob nagrevaniya i okhlazhdeniya tormoznykh barabanov barabanno-kolodochnogo tormoza transportnogo sredstva dlya otsenki ikh teplovogo balansa / A. I. Vol'chenko, V. M. Pavliskiy, N. A. Vol'chenko, D. A. Vol'chenko, P. A. Polyakov. zayavitel' i patentoobladatel' IvanoFrankovsk. natsional. un-t nefti i gaza. №2012110869/11; zayavl. 21.03.2012; opubl. 10.08.2014 Byul. №22. $11 \mathrm{~s}$.

4. Pat. 2386061 S2 RF, MPK F16D 49/08; F16D 65/813. Sposob opredeleniya koeffitsiyentov raspredeleniya teplovykh potokov mezhdu parami treniya razlichnykh tipov friktsionnykh uzlov v lentochno-kolodochnykh tormozakh burovykh lebedok (varianty) / A. I. Vol'chenko, D. A. Petrik, N. A. Vol'chenko, D. A. Vol'chenko; zayavitel' i patentoobladatel' Ivano-Frankovsk, natsional. tekhn. un-t nefti i gaza. - №2007128496/11; zayavl. 24.07.2007; opubl. 10.04.2010. Byul. №10. - $14 \mathrm{~s}$.

5. Proyektnyy i proverochnyy raschet friktsionnykh uzlov barabanno- i diskovokolodochnykh tormozov avtotransportnykh sredstv. Standart / A. X. Dzhanakhmedov, A. I. Vol'chenko, N. A. Vol'chenko i dr. Baku: Apostroff, 2016.264 s.

6. Tsvetkov F. F., Grigor'yev B. A. Teplomassoobmen. M.: Izd-vo MEI, 2005. - 215 s. 